\title{
The main morphological trends in the development of the foraminiferal aperture and their taxonomic significance
}

\author{
VALETIA MIKHALEVICH ${ }^{1}$ \& JEAN-PIERRE DEBENAY ${ }^{2}$ \\ ${ }^{1}$ Department of Protozoology, Zoological Institute RAS, Saint Petersburg, 199034, Russia. (e-mail: raskin@AK1266.spb.edu) \\ ${ }^{2}$ Laboratoire de Géologie, UPRES EA 2644, Fac. Sciences, 2 Bd Lavoisier, 49045 Angers Cedex, France. (e-mail: debenay@univ-angers.fr)
}

\begin{abstract}
As a result of the intensive movement of the cytoplasm through the aperture when communication with the environment is required, this area has an important and variable functional burden. Additional skeletal structures have a fundamental supporting function along the course of this strong cytoplasmic stream and may be related to the compartmentalization and differentiation of the cytoplasm. As a result of these important functional roles, the structure of the aperture is one of the basic diagnostic features in foraminiferal taxonomy.

The simplest and least diverse apertural types are found in the most ancient unilocular or pseudochambered representatives of the classes Lagynata and Astrorhizata. Their development from simple to complicated ones in the different classes (following the new foraminiferal macrosystem proposed by Mikhalevich) shows a significant number of parallelisms and convergences.

In both the lower agglutinated groups and the higher calcareous members of the classes Spirillinata, Miliolata, Nodosariata and Rotaliata, the evolutionary trends of the apertures are similar within the same class, even if those of the lower groups are always structurally simpler and less diversified. These trends continue until all the possibilities of the pre-existing structures are exhausted. Then, new structures, sometimes affecting the whole cell organization arise and the possibilities of morphological changes multiply, leading to evolutionary divergence. J. Micropalaeontol. 20(1): 13-28, July 2001.
\end{abstract}

\section{INTRODUCTION}

The foraminiferal aperture is the area where the communication between the inner test cytoplasm and the environment occurs. The capture of food, locomotion, sense of touch, formation of new chambers as well as cysts, and the envelope around the 'nuptial cyst' during gamontogamy are all achieved by the pseudopods when they extrude through the aperture. In connection with the intensive movement of the cytoplasm in this area, the aperture has an important and variable functional burden. This explains the formation of many additional skeletal structures both outside and inside the aperture. The longitudinal ribs, plates, tubes or teeth inside the aperture undertake fundamental supporting functions for the strong cytoplasmic stream and are mostly developed in elongated forms (in Miliolata, Nodosariata and in some Rotaliata [Buliminida, Bolivinitida]). As a result of the important functional role of the aperture, its structure is one of the basic diagnostic features in foraminiferal taxonomy.

The foraminiferal aperture has had its own evolutionary development during the course of geological time, along with the evolution of the test morphology and test wall. It may be single or multiple. It is extremely variable in its form (rounded, oval, loop-shaped, fissure-like, arch-shaped, triangular, star-shaped, zigzag, radial, sieve-like or dendritic) and in its position, both with regards to the last chamber (terminal or at the base of the apertural face) and to the whole test (at the peripheral margin, on the umbilical or on the spiral side). It may be significantly complicated by external or, especially, by internal skeletal structures. Special attention is given to the evolution from single to secondarily multiple apertures, considered to be a polymerization process, or from primarily multiple to single apertures considered to be an oligomerization process. The apertures connected to stolons and canal systems, here named the 'integrative system', are also considered.
Significant attention has been given to apertural structures and to their taxonomic value by Hofker (1951, 1956, 1969, 1970). In previous work, they were mainly used for taxonomy, generally at a generic level, in limited groups such as miliolids (e.g. Luczkowska, 1972; Levy et al., 1991), unilocular forms (e.g. Le Calvez, 1947; Taylor et al., 1985; Patterson \& Pettis, 1986; Patterson \& Richardson, 1987), rotaliids (e.g. Müller-Merz, 1980; Billman et al., 1980) or planktonic forms (e.g. Poore \& Gosnell, 1985). Apertural characteristics have also been used for general phylogenetic purposes (e.g. Cushman, 1928; Loeblich \& Tappan, 1964) but the apertural development was not particularly stressed. Recently, a revision of some calcareous groups (Discorbidae, Rosalinidae, Rotaliidae, Bolivinitidae, Anomalinidae, Alabaminidae, Cancrisidae and Gavelinellidae) was undertaken by Hansen \& Revets (1992) and by Revets (1996). Here, the revision was fully based on the apertural structures that were shown to be workable at family level.

This paper is devoted to the morphology of the apertural structures, and to the evaluation of their significance in the main foraminiferal classes. The classes considered in this paper correspond to those proposed by Mikhalevich (1980-98) in her new foraminiferal macrosystem. Very short descriptions of these classes are given below.

\section{THE MIKHALEVICH MACROSYSTEM}

The widely accepted classification of Loeblich \& Tappan (1988) regards the Foraminifera as being composed of 12 groups of equal taxonomic level; considered as suborders. It includes all the agglutinated forms in one group, in spite of their substantially heterogeneous morphological features. This classification was immediately considered as extremely useful (Haman, 1988; Banner, 1988). Most of the subsequent authors have retained it 
with the same number of suborders, or upgraded some superfamilies to suborder (e.g. Decrouez, 1989; Hart \& Williams, 1993; Debenay et al., 1996). However, Haman (1988) regretted that more rigourous criteria were not used and Haynes (1990) complained that the authors had not been able to push through a more thorough, logical, hierarchical scheme; the diagnoses being vague and even contradictory. Wall composition and fine structure were considered as most important at the suprageneric level, though there are inconsistencies (Haynes, 1990). In their classification of 1988, Loeblich \& Tappan considered the Foraminifera to be a single order. Later, following Lee (1990), they considered them to be a class including 14 orders. This separated their former Textulariina into 4 orders (Loeblich \& Tappan, 1992). This is in agreement with the opinion of Haynes (1990) who suggested that the Foraminifera should be upgraded to at least a class or subclass, considering their position as the largest and most varied group of invertebrates with a unique mode of reproduction. In the 'Principles of Classification' that he gave in the same paper, he considers that 'even class status may provide too narrow a framework for the complexity of the relationships to be expressed'. Earlier, Margulis (1974) had suggested that this group should be considered as a phylum, which has been done in Five Kingdoms (Margulis \& Schwartz, 1988). The detailed classifications described by previous authors, especially Loeblich \& Tappan, make it possible to deal with the next step in taxonomic investigations. On this basis, it was possible for Mikhalevich (1980-98) to propose a new concept of foraminiferal evolution and to describe her new 'Macrosystem'.

The classificatory system proposed by Mikhalevich (1980-98) assigns paramount importance to the whole organization of the test, considering the composition and the ultrastructure of the test wall as an important, but subsidiary, feature. Thus, both agglutinated and calcareous taxa that are morphologically similar are unified in a single class. The evolution of the calcareous wall from agglutinated ancestors is supposed to have taken place in parallel in most of the foraminiferal classes, its ultrastructure differing only in the higher representatives of these phylogenetic branches. According to these views, the Foraminifera are considered to be a phylum which includes seven classes (Lagynata, Astrorhizata, Spirillinata, Miliolata, Nodosariata, Rotaliata and Globigerinata), eight subclasses and 63 orders. The classes Spirillinata, Miliolata, Nodosariata and Rotaliata are composed of both less evolved agglutinated subclasses (Ammodiscana, Schlumbergerinana, Hormosinana and Textulariana, respectively) and more highly evolved calcareous ones (Spirillinana, Miliolana, Nodosariana and Rotaliana, respectively). Only the higher subclasses have a typical calcareous wall ultrastructure, which is characteristic in each of them and may be used as a taxonomic feature at the subclass level ('monocrystalline', porcelaneous, hyaline radial, bilamellar).

\section{Class Lagynata}

Shells primitive unilocular, sometimes passing to pseudomultichambered ones with sub-sphaerical, elongated or very often irregular forms, organic shell wall, aperture simple or sometimes not developed.

\section{Orders Lagynida, Allogromiida and Ammoscalariida} (heterogeneous, insufficiently studied)

\section{Class Astrorhizata}

Shells of the same characteristics as in Lagynata but with agglutinated or microgranular wall, often of considerable thickness.

\section{Orders Astrorhizida, Dendrophryida, Saccamminida, Parathuramminida, Hippocrepinida}

\section{Class Spirillinata}

Shells pseudo-bilocular, a spherical proloculus followed by a long tubular second pseudo-chamber differently coiled. This initial tubular part is usually preserved, with the evolution of multi-chambered tests in the evolutionary more advanced forms. In these advanced forms, the aperture may have a characteristic curved or T-shaped apertural plate but in the majority of the other forms it is usually simple, located at the end of the tubular chamber. Moreover, the higher representatives may have additional apertures and, sometimes, a primitive canal system.

\author{
Subclass Ammodiscana \\ Orders Ammodiscida, Lituotubida \\ Subclass Spirillinana \\ Superorder Archaediscoida \\ Orders Lasiodiscida, Archaediscida \\ Superorder Involutinoida \\ Orders Involutinida, Hottingerellida \\ Superorder Spirillinoida \\ Orders Spirillinida, Patellinida
}

\section{Class Miliolata}

Shells mostly multi-chambered, predominantly with tubular chambers coiled in one of the special miliolide arrangements, usually two, rarely three per volution; sometimes planispiral with more than three broad chambers per whorl in the Order Soritida. The flexostyle is preserved in many representatives. Aperture at the end of the chamber may be simple or complicated by an inner tooth or a special structure. It may also be cribrate. Additional apertures only as an exception; integrative systems presented only by stolons.

Subclass Schlumbergerinana
Order Schlumbergerinida
Subclass Miliolana
Superorder Cornuspiroida
Orders Squamulinida, Cornuspirida, Costiferida
Superorder Milioloida
Orders Nubeculariida, Miliolida, Soritida

\section{Class Nodosariata}

Shells predominantly multichambered with the prevalence of elongated, mostly monoaxial (uni-, bi- or triserial) arrangements, sometimes in polymorphinoid or plectofrondicularian arrangements, more rarely planispiral (usually involute). Aperture terminal even in coiled forms, simple or complicated: radial, hooded, fissure-like, rarely cribrate. An entosolenian tube may be present in each of these apertural types (except in the cribrate one), only rarely forming inter-connected systems. No additional apertures or canal system are present. 
Morphology of the foraminiferal aperture

\author{
Subclass Hormosinana \\ Orders Hormosinida, Nouriida, Pseudopalmulida \\ Subclass Nodosariana \\ Orders Lagenida, Nodosariida, Plectofrondiculariida, \\ Colaniellida, Polymorphynida, Vaginulinida
}

\section{Class Rotaliata}

Tests exclusively multi-chambered, mostly planispiral or trochospiral or derived from both of them. Aperture commonly at the base of the apertural face, at least in the earlier stages, single or multiple, may be cribrate, simple or complex with welldeveloped and diversified inner plates, grooves, valves, often forming inter-connected systems. Additional apertures present, stolons and canal systems well developed.

\author{
$\underline{\text { Subclass Textulariana }}$ \\ Superorder Lituoloida \\ Orders Haplophragmiida, Lituolida, Cyclolinida, \\ Spiroplectamminida, Biseriamminida \\ Superorder Fusulinoida \\ Orders Endothyrida, Fusulinida \\ Superorder Trochamminoida \\ Order Trochamminida \\ Superorder Ataxophragmioida \\ Order Ataxophragmiida, Textulariida \\ Subclass Rotaliana \\ Superorder Robertinoida \\ Order Robertinida \\ Superorder Buliminoida \\ Orders Stilostomellida, Bolivinitida, Cassidulinida, Buliminida, \\ Delosinida \\ Superorder Discorboida \\ Orders Rosalinida, Discorbida, Glabratellida, Planorbulinida, \\ Asterigerinida, Chilostomellida, Orbitoidida, Rotaliida \\ Superorder Nonionoida \\ Orders Nonionida, Elphidiida, Nummulitida \\ Superorder Seabrookinoida \\ Order Seabrookinida
}

\section{Class Globigerinata}

Tests derived from Rotaliata, having the typical arrangement of the chambers found in that group, mostly trochospiral or planispiral but with a strong specialization of the test and of the aperture adapted to the pelagic mode of life (often enlarged, high-arched, gaping), inner apertural plates forming interconnected system only rarely present, additional apertures strongly developed.

\section{Orders Heterohelicida, Globigerinida, Globorotaliida, Hantkeninida}

\section{APERTURES IN LAGYNATA AND ASTRORHIZATA (1 AND 2)}

In the representatives of the most primitive and ancient classes (Lagynata, Astrorhizata; Pl. 1, figs 1-16) which had arisen in the Cambrian or earlier (Plotnikova, 1991; Pawlowski et al., 1999), some species without a definite aperture occur (Pl. 1, figs 1, 2). The aperture in these forms is functionally replaced by small openings between the sand particles (e.g. Rhumblerinella,
Myxotheca [Lagynata], Psammosphaera, Psammophax, Hemisphaerammina, Stegnammina [Astrorhizata]). In species possessing an aperture, there may be one, two, or several apertural openings. The multiple aperture with irregular openings of some Lagynata and Astrorhizata do not usually have a fixed position (e.g. Microcometes, Cribratina [Lagynata], Thurammina, Astrammina, Orbulinelloides [Astrorhizata]) (P1. 1, figs $3,4,5)$. This is regarded as a primarily multiple aperture, as opposed to the secondarily multiple aperture which is found in the most highly developed classes (Miliolata, Nodosariata, Rotaliata) and formed on the basis of their preceding singular aperture. Thus, the presence of a single aperture (e.g. Apogromia [Lagynata], Technitella, Colonammina, Lagenammina [Astrorhizata]) (Pl. 1, figs 9-16) or of two apertures (e.g. Pseudoditrema, Phainogullmia [Lagynata], Amphifenestrella, Amphitremoida [Astrorhizata]) (Pl. 1, figs 7, 8). These usually have a definite form and a fixed position and can, therefore, be regarded as the result of a progressive oligomerization from the primitive multiple aperture. On the other hand, the secondary multiple aperture in the higher classes can be regarded as the result of a progressive polymerization.

In the tubular forms of the Lagynata, (Shepheardella) and Astrorhizata (Rhabdammina, Oculosiphon, Rhizammina) the apertures are situated at the end of the tube (Pl. 1, figs 6, 12). In both of these classes, evolution gives rise to only the most primitive additional apertural structures. It may be slightly protruded on a neck or on a papilla; it may also have an external border (Sacculinella, Technitella, Thuramminopsis [Astrorhizata]). Structures similar to the entosolenian tubes of the Nodosariata are sometimes found (Allogromia [Lagynata], Ovammina [Astrorhizata]) (Pl. 1, figs 11, 16). These basic types of apertural structures in these classes are the same throughout their long geological history.

\section{APERTURES IN SPIRILLINATA (3)}

The aperture of the representatives of the class Spirillinata (Cambrian to Recent) is also rather simple (Pl. 1, figs 17-24). The rounded or oval opening is terminal, situated at the end of a long tubular pseudo-chamber, and usually not possessing a bordering lip (Ammodiscus, Ammovertella, Ammovertellina [subclass Ammodiscana], Spirillina, Trocholina, Turrispirillina [subclass Spirillinana]) (Pl. 1, figs 17-22). Depending on the type of coiling (irregular streptospiral, planispiral, trochospiral, uncoiled and rectilinear at the end), the position of the aperture on the test changes. In planispiral forms it is peripheral (Spirillina, Angulodiscus) (P1. 1, figs 19, 20). In trochospiral forms it may be peripheral (Pl. 1, fig. 21) but it moves to the umbilical side, and tends to become adjacent to the umbilicus (Pl. 1, fig. 22). However, even in this case it remains at the end of the tubular pseudo-chamber. In more advanced trochospiral forms (Glomotrocholina, Howchinia, Lasiotrochus, Conicospirillina, Michostomina), especially in those with additional material in the umbilical region and in species with multichambered tests, the aperture is always on the umbilical side. It displays a variety of morphologies (Pl. 1, figs 22, 23). In some of the advanced trochospiral forms, additional apertures and a primitive canal system developed (P1. 1, fig. 24) and in rare multi-chambered calcareous Recent forms (order Patellinida Mikhalevich, 1992), the aperture is located on the umbilical side 

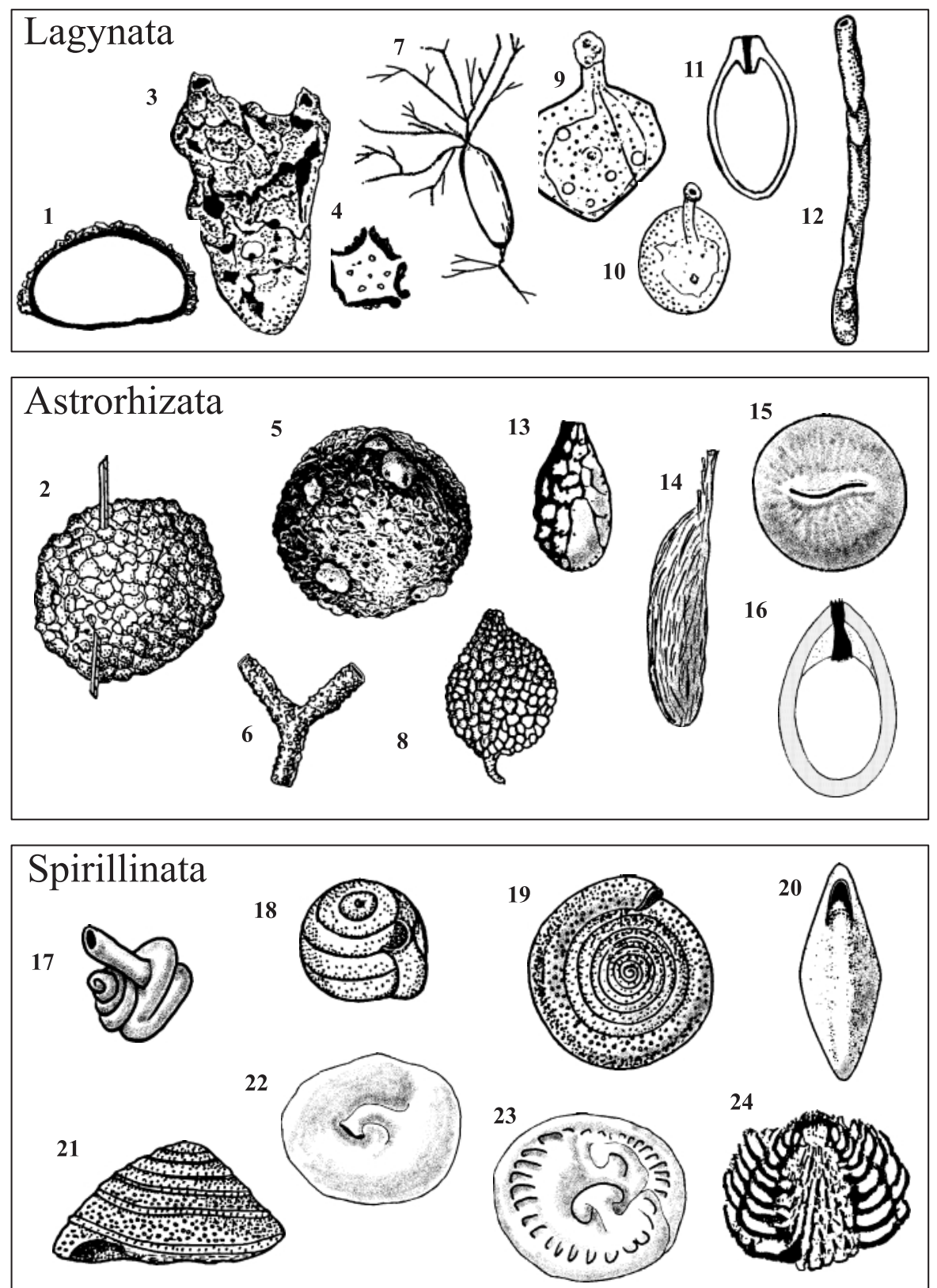

Explanation of Plate 1

Lagynata and Astrorhizata: fig. 1. Myxotheca (Lagynata) - section, aperture not developed; fig. 2. Psammosphaera (Astrorhizata) - test without definite aperture; fig. 3. Cribratina (Lagynata) - primary-multiple aperture; fig. 4. Microcometes (Lagynata) - primary-multiple aperture; fig. 5. Orbulinelloides (Astrorhizata) - primary-multiple aperture; fig. 6. Heterogromia (Lagynata) - aperture at the end of a neck; fig. 7. Paralieberkuehnia (Lagynata) - aperture at the end of the neck, with a small border; fig. 8. Allogromia (Lagynata) - section, aperture with entosolenian tube; fig. 9. Xenothekella (Lagynata) - aperture at the end of the tubular chamber; fig. 10. Lagenammina (Astrorhizata) - aperture at the narrowing end of the test; fig. 11. Technitella (Astrorhizata) - aperture at the end of the elongated neck; fig. 12. Pilulina (Astrorhizata) - aperture as a curved fissure with a small lip; fig. 13. Ovammina (Astrorhizata) - aperture with entosolenian tube; fig. 14. Phainogullmia (Lagynata) - test with two apertures; fig. 15. Armorella (Astrorhizata) - test with two apertures; fig. 16. Rhabdammina (Astrorhizata) - apertures at the open ends of the tubes. Spirillinata: fig. 17. Ammovertellina (Ammodiscana) - terminal aperture; fig. 18. Repmanina (Ammodiscana) - aperture at the end of the tubular pseudo-chamber; fig. 19. Spirillina (Spirillinana) - aperture on the peripheral margin, at the end of the tubular pseudochamber; fig. 20. Angulodiscus (Spirillinana) aperture on the peripheral margin, at the end of the tubular pseudo-chamber; fig. 21. Trocholina (Spirillinana) - aperture on the peripheral margin slightly displaced to the umbilical side, at the end of the tubular pseudo-chamber; fig. 22. Mychostomina (Spirillinana) - aperture at the end of the tubular pseudo-chamber, in the umbilical area; fig. 23. Patellina (Spirillinana) - aperture in the umbilical area, covered by a T-shaped plate; fig. 24. Lasiotrochus (Spirillinana) - canal system. 
and may be covered by a curved (T-shaped, S-shaped) plate; a condition not found in other foraminiferal taxa (Pl. 1, fig. 23).

This peculiar, rather primitive group did not produce either multiple apertures or inner apertural complications during its development and, in the majority of cases, has no external structure. Nevertheless, the presence of additional apertures and a canal system demonstrates the high degree of complexity achieved by some of its representatives which died out in Palaeozoic (Lasiodiscida) and Jurassic (Spirotrocholinina) times. The displacement of the aperture to the umbilical side in many of the trochoid forms is also regarded as a progressive feature.

\section{APERTURES IN MILIOLATA (4)}

The first certain occurrences of the class Miliolata are reported from Carboniferous strata, but have probably existed since Ordovician times. The apertures of the representatives of this class are more complex and variable (Pl. 2, figs 1-29). Their position in relation to the whole test is terminal in the overwhelming majority of the species, not only in the rectilinear or erect forms but also in the forms coiled in one of the typical miliolid types. Only in the less numerous, planispirally coiled, representatives of this group (mainly multi-chambered alveolinids and soritids) may the aperture (usually a row of openings) be peripheral in position. But, even in this case, it has a terminal position on the last chamber, and is never connected with the base of the apertural face. Neither have we ever found the aperture situated at the base of the apertural face in peneroplids (Pl. 2, figs 27-29).

In more primitive representatives, the aperture is simple (Pl. 2, figs 1-6) and often at the end of an elongated neck surrounded by a small border or by a broad everted lip (Pl. 2, figs 1-3). The external apertural flap (previously considered to be an external tooth) may also result from an external apertural complication (e.g. Miliolinella, Biloculinella, Sigmoinella, Sigmopyrgo, Pateoris, Pyrgoella, Scutuloris) (P1. 2, figs 7, 8; Pl. 6, figs 1-4).

The next stage of apertural complexity is the development of inner teeth, the origin of which is not known in detail, except in some cases where it is formed as a fold of the chamber wall (Pl. 2, fig. 9) (Mikhalevich, 1988, Pl. 6, fig. 1b). The majority of the evolutionary advanced miliolids possess inner teeth of variable complexity (e.g. Pyrgo, Spiroloculina, Cribrolinoides, Quinqueloculina, Sigmoilina, Dentostomina, Idalina, Ptychomiliola, Podolia, Tortonella, Nevillina, Flintina) (P1. 2, figs 9-21; P1. 6, figs 5-8, 10). Their structure changes from simple to complicated (bifid, circular or with different configuration (P1. 2, figs 11-21; Pl. 6, fig. 10) and from single to multiple (P1. 2, figs 15, 17). Here, the process of polymerization can be observed.

The multiple teeth may fuse, forming a secondarily multiple aperture ('tooth divided multiple aperture') (P1. 2, figs 14, 16, 18-20; Pl. 6, fig. 10) that may become radial in some cases (Pl. 2, figs 16,19$)$. However, this radial structure derived from the teeth is morphologically different from the radial aperture typical of some of the genera of the Nodosariata. Changes in the number and structure of the miliolid teeth during their ontogeny allow us to speculate about their phylogenetic development (Dentostomina, Podolia, Tortonella, Cribrolinoides, Massilinoides, Idalina, Bidentina, Flintina) (Pl. 2, figs 17-19; Mikhalevich, 1983, p. 129, figs 233-237). The complex miliolid teeth not only create additional supporting elements, aiding strong cytoplasmic streaming in the narrow apertural passage, but may also lead to the partial differentiation of this cytoplasmic stream.

The development of secondary openings from a previous single aperture (polymerization) leads to the formation of a multiple aperture ('areal secondarily multiple aperture') (Pl. 2, fig. 26; Pl. 6, fig. 9). A cribrate aperture may be formed on the basis of a complex inner tooth (Pl. 2, figs 14, 16, 18-20; Pl. 6, fig. $10)$ or a convex cribrate plate supported by pillars from beneath - the trematophore ( $\mathrm{Pl}$. 2, figs 22-25). The process of formation of a secondarily multiple aperture takes place in the different lineages of the miliolid type (Involvohauerina, Cribropyrgo, Pyrgoella, Tortonella, Nevillina, Hauerina, Pseudohauerina, Parahauerinoides, Heterillina, Poroarticulina, Periloculina, Pseudofabularia) (P1. 2, figs 14, 16, 18-20, 22-26; P1. 6, figs 9-12), as well as in alveolinids and in the representatives of the order Soritida (Conicospira, Peneroplis, Dendritina, Archaias, Sorites, Borelis) (P1. 2, figs 27-29).

Even if they are less developed than in the higher subclasses, the inner apertural structures are also found within the representatives of the lower subclass of the Miliolata (Schlumbergerinana) with single or multiple teeth (Dentostomina, Silicomassilina, Trilocularena, Silicosigmoilina), or a cribrate aperture (Schlumbergerina) (P1. 2, figs 17, 22).

Thus, during the process of evolution of this class, the apertural apparatus achieved significant complexity. It is characterized by its peculiar tooth-apparatus, not observed in any other foraminiferal taxa, but the teeth of the neighbouring successive chambers in the Miliolata are never connected into a continuous system from chamber to chamber. The only inner continuous systems in higher Miliolata (Soritidae) are the stolons occurring in forms lacking the teeth. The additional apertures and the canal system are practically absent in this group (except the additional apertures in Polysegmentina and Parahauerinoides). Representatives with a simple aperture have existed from the most ancient times until the present day.

\section{APERTURES IN NODOSARIATA (5)}

The apertural apparatus of the class Nodosariata (Pl. 3) which is known from the Ordovician to the Recent, is characterized by various structures of different complexity. The aperture may be simple with various outlines (rounded, oval, triangular, etc; Pl. 3, figs 1-3) often at the end of an elongated neck (Pl. 3, fig. $4 \mathrm{a}, \mathrm{b})$ and, more rarely, with a small border or a collar ( $\mathrm{Pl}$. 3 , fig. 4c, d). It may be fissure-like, sometimes asymmetrical (often like a hood) (Pl. 3, figs 5-10) or radial (Pl. 3, figs 11-18). Previously, little attention was paid to the fact that both the radial and the asymmetrically fissured apertures are found not only in the higher Nodosariata with a hyaline radial wall but also in some uniserial agglutinated forms (e.g. Nodosinum, Cuneata; Pl. 3, figs 5, 11). This fact strongly suggests a relationship between these groups (Mikhalevich, 1992, 1998, 1999) to the extent that these apertural types have never been observed in any other foraminiferal taxa. It is corroborated by the similarities between the test morphology of the higher calcareous Nodosariata and of the uniserial agglutinated forms. On this basis, these forms were removed from the Textulariacea and 


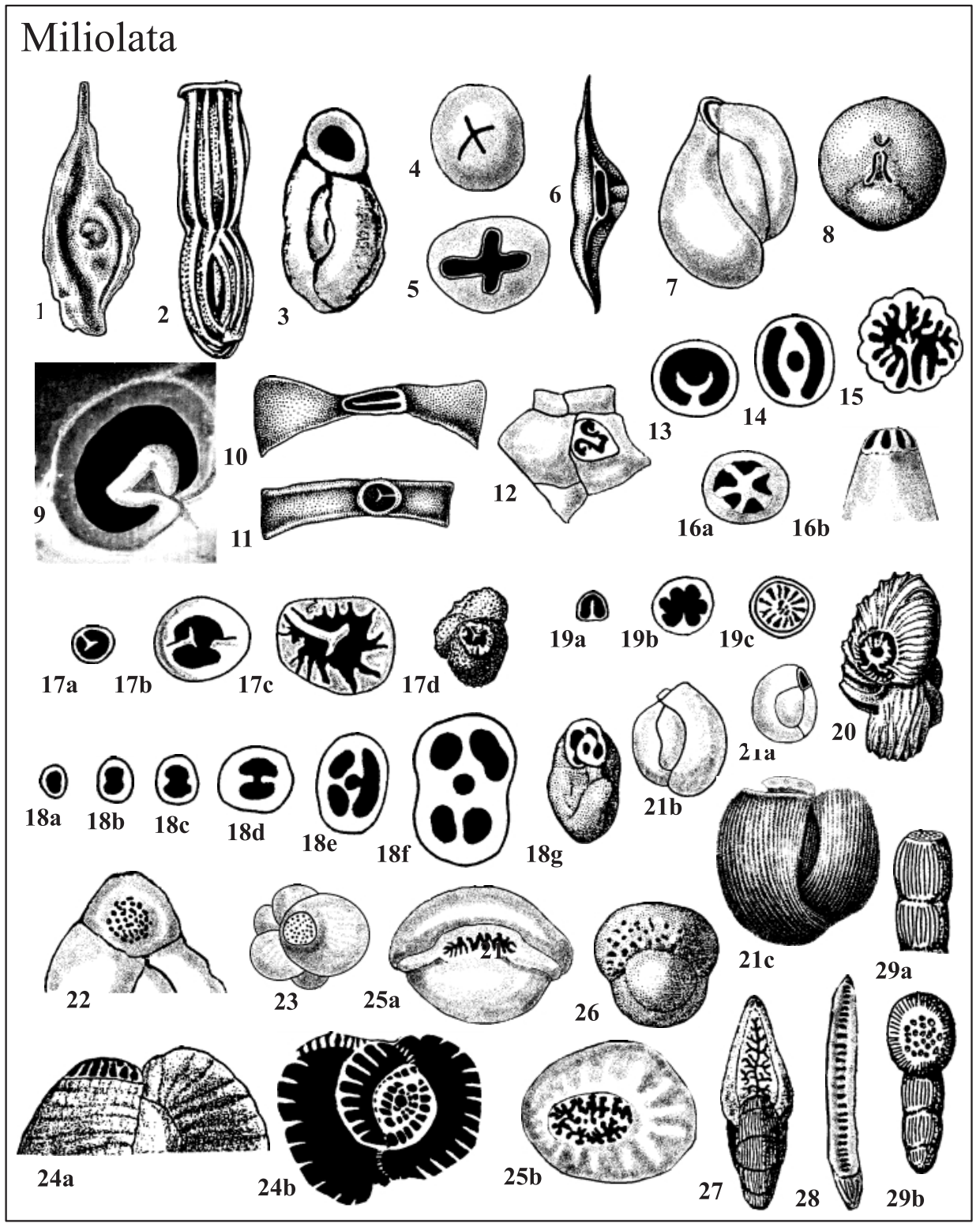

Explanation of Plate 2

Fig. 1. Palaeomiliolina (Miliolana) - simple aperture at the end of an elongated neck; fig. 2. Articulina (Miliolana) - simple aperture with a broad border; fig. 3. Wiesnerella (Miliolana) - simple aperture with a broad everted lip; fig. 4. Nodophtalmidium (Miliolana) - terminal cruciform aperture; fig. 5. Rupertianella (Miliolana) - simple aperture with a lip; fig. 6. Edentostomina (Miliolana) - simple aperture; fig. 7. Miliolinella (Miliolana) aperture with a flap; fig. 8. Pyrgoella (Miliolana) - aperture with a flap; fig. 9. Pyrgo laevis (Miliolana) - EM $(\times 1000)$, structure of the inner tooth (from Mikhalevich, 1988); fig. 10. Spiroloculina (Miliolana) - aperture with simple tooth; fig. 11. Spiroloculina (Miliolana) - aperture with bifid tooth; fig. 12. Podolia (Miliolana) - complex tooth gives lyre-shaped appearance to the aperture, in the early stages the tooth is simple; figs 13, 14, 15. bifid tooth $(\mathbf{1 3})$ and complex teeth $(\mathbf{1 4}, \mathbf{1 5})$ of different Miliolata; fig. 16a, b. Nevillina (Miliolana) - multiple radial teeth fuse, forming a multiple aperture divided by teeth (a, apertural view, b, edge view); fig. 17a-d. Dentostomina (Schlumbergerinana) - a, b, c, apertural structure from different growth stages; d, apertural view of the test (from Mikhalevich, 1983); fig. 18a-g. Tortonella (Miliolana) - a-f, apertural structure from different growth stages; $\mathbf{g}$, apertural view of the test (from Didkov'skij, 1957); fig. 19a-c. Idalina (Miliolana) - apertural apparatus from different growth stages (from Munier-Chalmas \& Schlumberger, 1885); fig. 20. Cribrolinoides (Miliolana) - aperture with a complex annular tooth; fig. 21a, b, c. Flintina (Miliolana) - apertural apparatus from different growth stages (from Mikhalevich, 1983); fig. 22. Schlumbergerina (Schlumbergerinana) - multiple aperture with trematophore; fig. 23. Miliola (Miliolina) - multiple aperture with trematophore; fig. 24a, b. Pseudohauerina (Miliolana) - multiple aperture with trematophore (a, edge view; b, section, pillars supporting trematophore are clearly seen (from Ponder, 1972); fig. 25a, b. Periloculina (Miliolana) - multiple aperture with trematophore through ontogeny (a, at the biloculine stage, $\mathbf{b}$, at the adult stage with the embracing last chamber) (from Munier-Chalmas \& Schlumberger, 1885); fig. 26. Involvohauerina (Miliolana) - areal multiple aperture; fig. 27. Dendritina (Miliolana) dendritic aperture; fig. 28. Peneroplis (Miliolana) - aperture as a row of openings; fig. 29. Coscinospira (Miliolana) - areal multiple aperture (a, side view, $\mathbf{b}$, top view). 


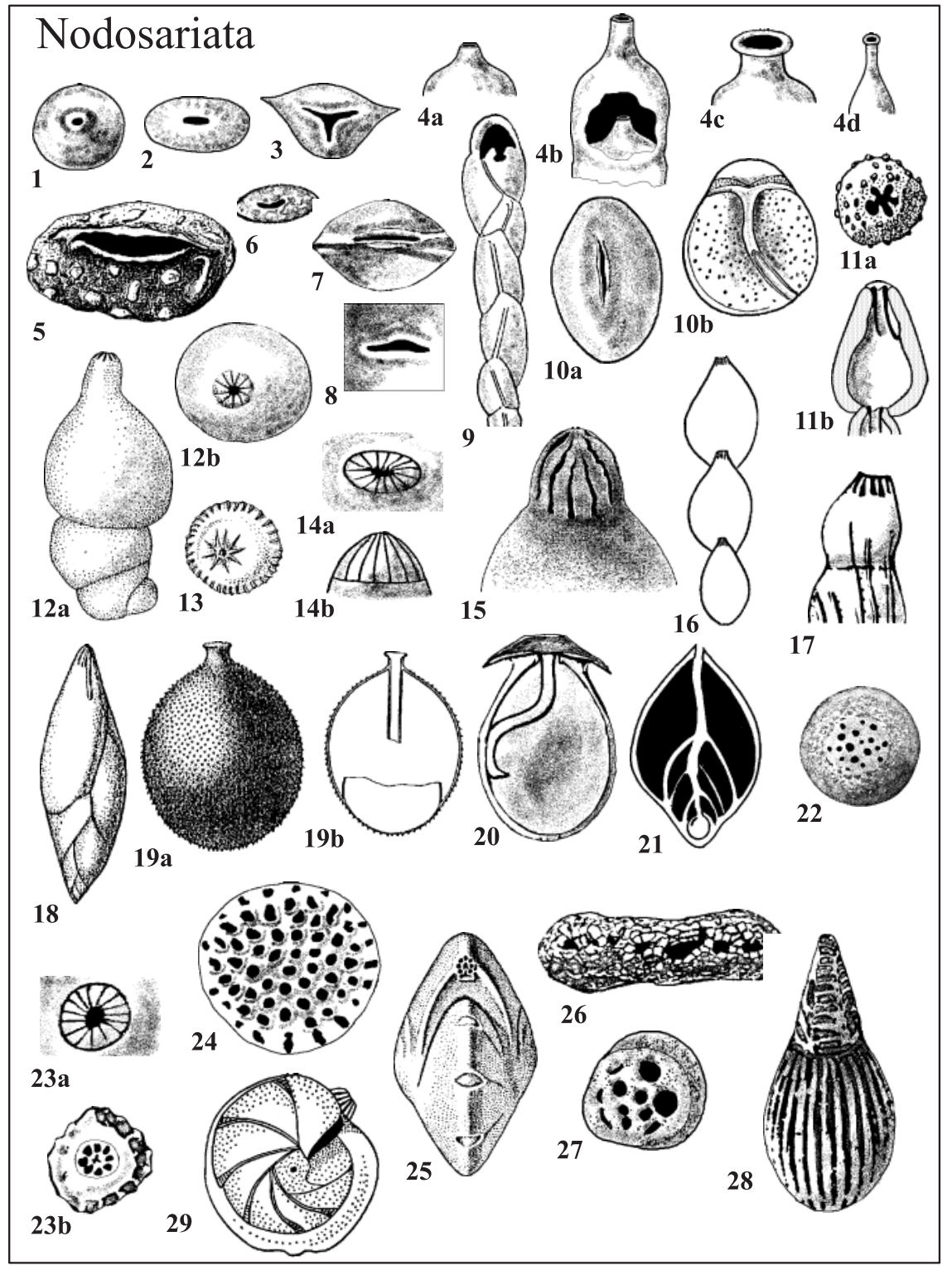

Explanation of Plate 3

Fig. 1. Lagenoglandulina (Nodosariana) - radial aperture, slightly elevated; fig. 2. Lingulonodosaria (Nodosariana) - oval aperture; fig. 3. Tollmania (Nodosariana) - triradial aperture; fig. 4a-d. Nodosariate aperture (Hormosinana) (a, on a short neck; b, at the end of an elongated neck; c, d, on a neck with a collar); fig. 5. Cuneata (Hormosinana) - asymmetrically fissured aperture; fig. 6. Psammolingulina (Hormosinana) - fissured aperture; fig. 7. Lingulina (Nodosariana) - fissured aperture; fig. 8. Parafissurina (Nodosariana) - hood-like aperture (entosolenian tube is not seen); fig. 9. Pleurostomella (Nodosariana) - hood-like aperture with entosolenian tube; fig. 10. Fissurina (Nodosariana) - asymmetrically fissured aperture with entosolenian tube ('asymmetrically fissured entosolenian aperture'); fig. 11a, b. Nodosinum (Hormosinana) - radial aperture (a, top view; b, longitudinal section, inner radial ribs are seen); fig. 12a, b. Hemirobulina (Nodosariana) - radial aperture (a, edge view; b, top view); fig. 13. Pseudonodosaria (Nodosariana) - aperture with external radial ribs; fig. 14a, b. scheme of the radial aperture (a, top view; b, edge view); fig. 15. Laevidentalina (Nodosariana) - radial aperture closed at the apex (multiple radial aperture); fig. 16. Nodosaria (Nodosariana) - longitudinal section, radial apertures are seen; fig. 17. Dentalina (Nodosariana) - radial aperture; fig. 18. Polymorphyna (Nodosariana) - radial aperture with entosolenian tube (radial entosolenian aperture); fig. 19a, b. Bombulina (Nodosariana) - simple-entosolenian aperture (a, test with the bordered elongated neck; b, longitudinal section) (from Mikhalevich, 1983); fig. 20. Irenita (Nodosariana) - view from the dorsal side: asymmetrically fissured entosolenian aperture with broad asymmetrically developed lips; fig. 21. Ellipsopolymorphina (Nodosariana) - longitudinal section showing interconnected entosolenian tubes (from Silvestri, 1904); fig. 22. Cribrolagena (Nodosariana) - primarily multiple aperture; fig. 23a, b. Amphimorphina (Nodosariana) - aperture at different stages of ontogeny (a, radial aperture of early stage, $\mathbf{b}$, radial multiple aperture of adult test) (from Loeblich \& Tappan, 1964); fig. 24. Cribrolenticulina (Nodosariana) - radial multiple aperture; fig. 25. Cribrorobulina (Nodosariana) - radial multiple aperture; fig. 26. Polychasmia (Hormosinana) - multiple aperture (a row of openings of irregular form); fig. 27. Cribratina (Hormosinana) - cribrate aperture; fig. 28. Pytine (Nodosariana) - rounded aperture at the end of the elongated neck, surrounded by a system of longitudinal and transverse ribs and by pillars going perpendicularly to the inner wall; fig. 29. Lenticulina (Nodosariana) - radial terminal aperture. 


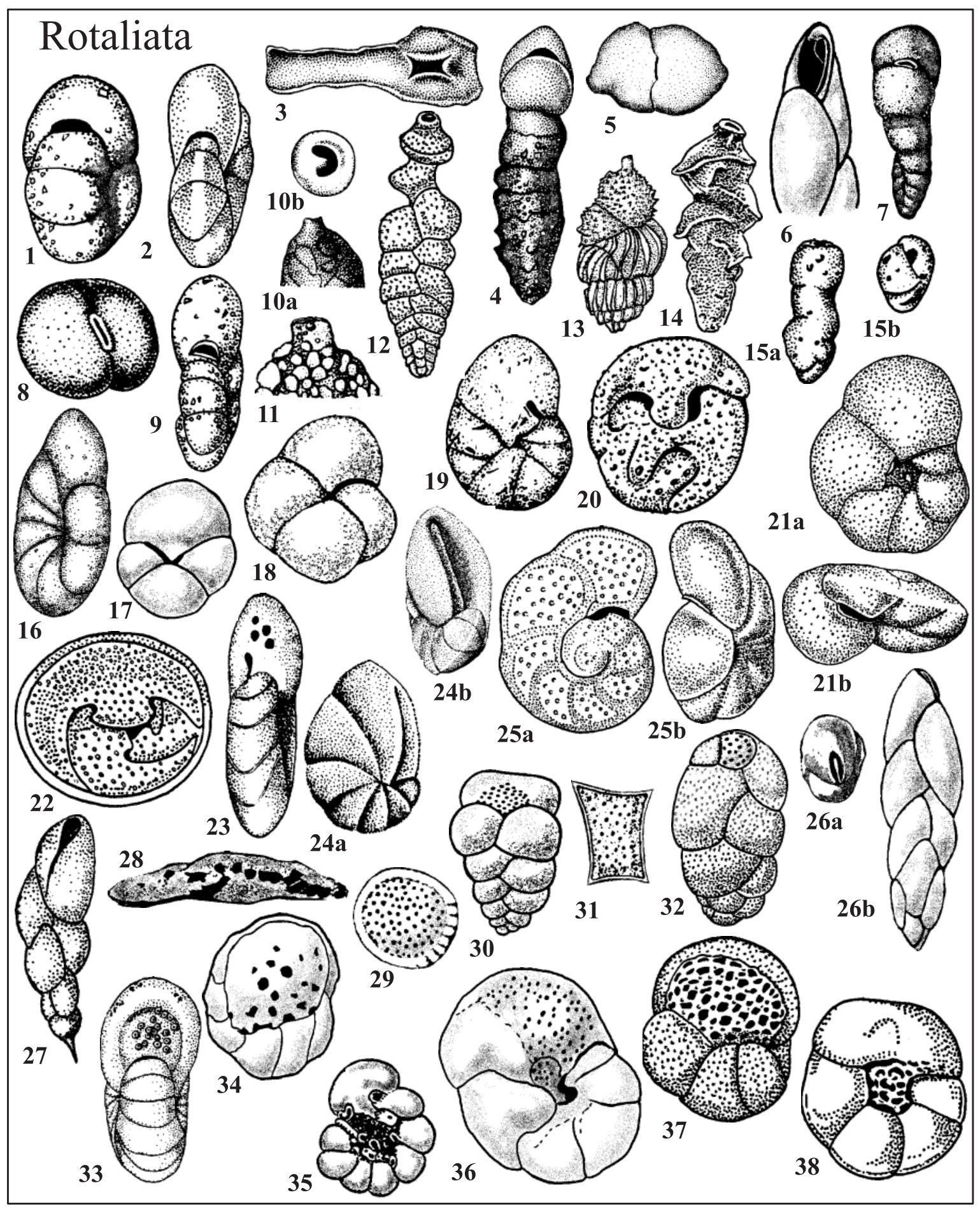


placed into the lower subclass Hormosinana of the class Nodosariata (Mikhalevich, 1992, 1995, 1997a, b, 1998, 1999).

The presence of the entosolenian tube hanging from the aperture into the chamber cavity in the Nodosariata (Pl. 3, figs $10,18-20)$ is another peculiar feature which is never observed in other foraminiferal taxa. This tube may be rather short, occupying not more than a third to a half of the last chamber length (many species of the Lagenida and Polymorphinida), or it may extend through the whole chamber, as for example in some Fissurina (Pl. 3, fig. 10). It may even curve back on one side of the test. In such cases, it may become semicylindrical at the end. Entosolenian tubes in higher Nodosariata occur under various apertural types: simple (Pl. 3, fig. 19), radial (Pl. 3, fig. 18), asymmetrically fissured (Pl. 3, figs 10, 20) or hooded (Pl. 3, fig. 9). Its presence not only underlines the profound morphological similarity of all the higher groups of the Nodosariata but also demonstrates their close relationship in spite of the variability of their test morphology. The presence of the entosolenian tube and of the asymmetrical hood-like aperture in the pleurostomellids is the rationale for placing them in the Nodosariata instead of the Rotaliata (Mikhalevich, 1993). In Pleurostomella, and in some other pleurostomellids (Ellipsopolymorphina, Ellipsoidina, Ellipsoidella) (P1. 3, figs 9, 21 ), the inner tubes of the successive chambers are connected with each other, forming a single system. This structure shows a high degree of development of the apertural apparatus, which may be related to the compartmentalization of the cytoplasm.

In unilocular calcareous Nodosariata (Lagenida), which we consider to be primarily unilocular (Cribrolagena), a primarily multiple aperture can be observed (Pl. 3, fig. 22). A secondarily multiple aperture developed in the higher multi-chambered Nodosariata (subclass Nodosariana) on the basis of the preceding radial aperture (Amphimorphina, Cribrolenticulina, Cribrorobulina) (Pl. 3, figs 23-25). However, a multiple aperture is not often found in this subclass, which may be due to the fact that their rather large aperture is already subdivided by radial structures. Multiple apertures (cribrate or as a row of openings) can also be observed in representatives of the lower subclass Hormosinana (P1. 3, figs 26, 27).

One of the peculiarities of the Nodosariata aperture is the rather strong development of the outer apertural structures (radiate outer ribs, ring-like ridges around the elongated necks, sometimes rather complicated constructions of longitudinal and transverse ribs, or very broad collars in some lagenids) (Pl. 3, figs $20,28)$. These outer structures not only strengthen the fragile elongated necks, but also support the cytoplasmic stream that extrudes through the aperture. Another specific type of aperture (apertural chamberlets) is also found only in this class (Heteromorphina).

The position of the Nodosariata aperture is always terminal, even in the spirally coiled forms, though in the latter case it may be somewhat displaced toward the peripheral margin (Pl. 3, figs $25,29)$. This terminal position of the aperture in the spirally coiled forms (along with the other features of their morphology) allows us to distinguish them easily from the spirally coiled tests of the Rotaliata. Thus, this structural feature may serve as a diagnostic criterion for taxa at a high taxonomical rank. Previously, it was used for the diagnoses of taxa at a lower rank (genera, sometimes families). The additional apertures are not developed in this group.

\section{APERTURES IN ROTALIATA (6)}

The higher Rotaliata have been known since the Triassic but the lower representatives of this class with an agglutinated wall

\section{Explanation of Plate 4}

Fig. 1. Haplophragmoides (Textulariana) - basal arched aperture; fig. 2. Nonion (Rotaliana) - basal fissured aperture; fig. 3. Tetragonostomina (Textulariana) - basal rectangular aperture bordered by elevated lips; fig. 4. Textilina (Textulariana) - basal arched aperture; fig. 5. Norvanganina (Textulariana) - basal fissured aperture; fig. 6. Stainforthia (Rotaliana) - loop-shaped aperture with narrow incurved lip at one margin and inner tooth plate (test with inner apertural system of interconnected tooth plates); fig. 7. Siphotextularia (Textulariana) - oval bordered opening slightly elevated above the base (areal); fig. 8. Karreriella (Textulariana) - oval bordered opening slightly elevated above the base (areal); fig. 9. Labrospira (Textulariana) - areal aperture bordered by a lip; fig. 10a, b. Cylindroclavulina (Textulariana) - a, edge view, terminal aperture at the end of a short neck; $\mathbf{b}$, top view, showing a tooth plate (test with an inner apertural system of inter-connected toothplates; early stages with a basal aperture); fig. 11. Clavulina (Textulariana) - terminal aperture at the end of a short neck (with an inner tooth plate; early stages with a basal aperture); fig. 12 . Spiroplectinata (Textulariana) - rounded terminal aperture of the adult stage at the end of a short neck; fig. 13. Euuvigerina (Rotaliana) - terminal aperture of the adult stage at the end of a short neck (with inner apertural system); fig. 14. Eouvigerina (Rotaliana) - bordered aperture of the adult stage on a short neck (with a short inner tooth plate); fig. 15a, b. Goesella (Textulariana) - aperture at different stages of ontogeny (a, basal loop-shaped opening of a young stage; $\mathbf{b}$, terminal opening of the adult stage) (from Mikhalevich 1983); figs 16-18. Trochammina (Textulariana) basal (interiomarginal) aperture of different species $(\mathbf{1 6}, \mathbf{1 7}$, on the umbilical side, entering peripheral margin; 18, aperture wholly on the umbilical side); fig. 19. Polystomammina (Textulariana) - loop-shaped main aperture on the umbilical side and partly on the peripheral margin; fig. 20. Tiphotrocha (Textulariana) - basal aperture under umbilical chamber lobe; fig. 21. Discorbis (Rotaliana) - basal aperture on the umbilical side (with inner valves) (a, umbilical side; b, apertural view); fig. 22. Neoconorbina (Rotaliata) - basal aperture under umbilical chamber lobe; fig. 23. Arenoparrella (Textulariana) - loop-shaped aperture connected with the base of the apertural surface and areal multiple aperture; fig. 24 . Megastomella (Rotaliana) - aperture as a long vertical fissure (connected with the base of the apertural surface) in deep fold of the apertural face; fig. 25. Cibicides (Rotaliana) - basal fissured aperture with a lip, going from the umbilical to the spiral side and entering the spiral suture (a, spiral side; b, umbilical side); fig. 26. Fursenkoina (Rotaliana) - elongated aperture connected with the base of the apertural face, free part of the toothplate projecting through the opening, opposite end attached to the previous foramen, forming inner apertural system (a, apertural view; b, edge view); fig. 27. Fursenkoina (Rotaliana) - comma-shaped aperture (lower part of the aperture closed, leaving only a suture to the base of the apertural face (toothplates of the inner apertural system are not seen); fig. 28. Poritextularia (Textulariana) - areal multiple aperture of the adult specimen (basal vertical elongated fissured aperture in the young stages); fig. 29. Coskinolina (Textulariana) - multiple aperture; fig. 30. Minouxia (Textulariana) multiple sieve-plate aperture; fig. 31. Chrysalidinella (Rotaliana) - areal multiple aperture of adult test (basal aperture with toothplate at the early stage); fig. 32. Sporobulimina (Rotaliana) - multiple sieve-plate aperture; fig. 33. Cyclammina (Textulariana) - basal fissured aperture and areal multiple one; fig. 34. Arenagula (Textulariana) - multiple sieve-plate aperture; fig. 35. Dobrogelina (Textulariana) - multiple sieve-plate aperture; fig. 36. Poroeponides (Rotaliana) - basal fissured aperture and areal multiple one; fig. 37. Neocribrella (Rotaliana) - multiple sieve-plate aperture; fig. 38. Sestronophora (Rotaliana) - multiple sieve-plate aperture. 
arose earlier, during the Carboniferous. It is one of the most diversified and thriving Recent foraminiferal groups.

\section{Main aperture}

One of the main features of the aperture of the Rotaliata is its position (at least initially) at the base of the apertural face, in the spirally coiled forms as well as in the elongated monoaxial forms (2-3 serial). In the spirally coiled forms (both plani- and trochospiral - interio-marginal aperture) (Pl. 4, figs 1, 2, 16-25, 36), it may be situated at the peripheral margin or on one of the sides. In the elongated monoaxial forms (2-3 serial), it is generally basal or at least connected with the base of the apertural face (e.g. Textularia, Textilina, Norvanganina, Gaudryina, Bolivina, Fursenkoina) (Pl. 4, figs 3-6, 26). In both enrolled and monoaxial forms, the aperture may be more rarely separated from the base (Pl. 4, figs 7-9) and may even become terminal in secondarily uncoiled forms (Pl. 4, figs 10-14). However, in this case, it usually has a characteristic basal position in the initial coils of the test ( $\mathrm{Pl}$. 4, fig. 15). The areal position of the aperture in this group also is supposed to be of secondary origin.

In both planispiral and trochospiral forms, the main aperture is usually a horizontal slit or arch (Pl. 4, figs 1, 2, 21, 33, 36) but sometimes may be loop-shaped (Pl. 4, figs 19, 23) or a vertical slit (Pl. 4, fig. 24). The horizontal slit-like aperture of trochospiral forms may be very long and may extend from the umbilical to the spiral side, crossing the peripheral margin and entering the spiral suture or even the intercameral sutures (some species of Cibicides, Gyroidina) (Pl. 4, fig. 25a, b). In the elongated monoaxial forms (2-3 serial), more often the aperture is slit-like (Pl. 4, fig. 5), arched (Pl. 4, fig. 4) or loop-shaped (P1. 4, figs 6, 26, 27), remaining connected with the base of the apertural face (e.g. Textularia, Gaudryina, Bolivina). The elevated (areal) aperture above the base of the apertural face (Pl. 4, fig. 9) and the terminal aperture (mainly in monoaxial forms) (Pl. 4, figs 10-14, 15a) may be circular or oval, at the end of an elongate neck, and sometimes encircled by a border or a collar. The representatives of the family Siphoninidae with a terminal aperture on an enrolled test present an exception to the rule but other features of their structure are more characteristic of the Rotaliata.

In the trochospiral forms the aperture more often becomes umbilical. In this case it may be connected with the additional umbilical apertures and with the umbilical ends of the chambers, acquiring a star-like or other irregular indented outline. Slit-like and arched apertures may be bordered by a small lip (Pl. 4, fig. 25) or may be situated under a folium of variable morphology (Hederina, Valvulineria, many forms among the Rotaliamminidae, Rosalinidae, Discorbidae) (Pl. 4, figs 20, 22). Slit-like and loop-shaped apertures may be situated on the flat or inflated surface of the apertural face, but also in a fold parallel or perpendicular to its base (Epistominella, Megastomella, Pseudoparella, Alabaminoides, Alexanderina) (P1. 4, fig. 24). Very often, the morphology and the disposition of the apertural flaps, of the edge of the septal surface and of the last chamber are similar (even in the minutest detail) in both the agglutinated representatives of the subclass Textulariana and the calcareous representatives of the subclass Rotaliana as, for example, in Tiphotrocha and Neoconorbina (P1. 4, figs 20, 22).
Secondary multiple apertures are observed in the two subclasses of the class Rotaliata, both in the elongated monoaxial forms (e.g. Cribrobigenerina, Cribrogoesella, Poritextularia, Marieita, Coskinolina, Ataxoorbignyna, Haurania [Textulariana] and Fijiella, Chrysalidinella, Sporobulimina [Rotaliana]) (Pl. 4, figs 28-31) and in the spirally coiled ones (e.g. Trochamminita, Lituola, Bulbophragmium, Acupeina, Orbitammina, Reissella [Textulariana] and Eponides, Poroeponides, Schlosserina [Rotaliana]) (Pl. 4, figs 23, 33-38).

Some genera have multiple openings on the apertural face and a simple one (slit-like, arched, loop-shaped) at the base of the apertural face (Arenoparella, Cyclammina, Poroeponides) (Pl. 4, figs $23,33,36)$. In this case, one could speculate that if the basal aperture disappears, there may only remain an areal opening above the base of the apertural face. Thus the areal aperture of Rotaliata, which is not connected with the base of the apertural face, is presumably of a secondary origin.

It is noteworthy that a multiple aperture occurs more often in the Textulariana than in the Rotaliana. This could obviously be explained by the setting up in the Rotaliana of the canal system, which enlarges their opportunities to communicate with the environment (Pl. 5, fig. 10). In the Textulariana, as well as in the Rotaliana, the multiple aperture may be formed not only on the apertural face of the last chamber but also on the plate that sometimes covers the aperture or the wide open umbilicus 'sieve-plate multiple aperture' (Arenagula, Dobrogelina [Textulariana], Neocribrella, Sestronophora [Rotaliana]) (P1. 4, figs $34,35,37,38$ ). Such sieve-plate apertures are never found in any other classes.

The near-mirror similarities between apertural morphology and structure (cribrate plates, flaps, folia) of both the Textulariana and Rotaliana, along with the similar tendencies of their ontogenetic development, show once more the kinship of these subclasses.

\section{Inner apertural structures}

As can clearly be seen from the examples given above, the structure of the Rotaliata aperture is extremely diverse. The greatest development and diversity are achieved by its inner apertural structures: grooves, valves, tooth plates, often of very complex arrangement (Pl. 5, figs 1-10). These inner complexities of the aperture are developed in the majority of the monoaxial elongated forms in the orders Buliminida, Bolivinitida, (superorder Buliminoida), forming a tooth-plate apparatus of different form and complexity: from a small plate (Turrilinoidea) or small tongue, to a groove, and hemicylindrical siphon (Eouvigerinoidea, Tubulogenerinoidea, Euloxostomoidea) as well as long complex plates.

These long complex plates may be curved or folded; they may also form a curl or outgrowth. These outgrowths may be dentate along their edge. They may jut out into the chamber lumen and/or may project above the apertural edge as a small tongue or rim (Milettioidea, Bolivinoidea) (Pl. 4, figs 6, 26, 27, Pl. 5, figs 1-6). The plates are sometimes attached to the wall of the preceding chamber.

One of the most complex and well developed tooth plates occurs in Bulimina as shown by Höglund (1947) and in Stainforthia (Kohl, 1985). In Bulimina, the plate consists of two parts with a free lateral outgrowth, the dentate edge of which is 

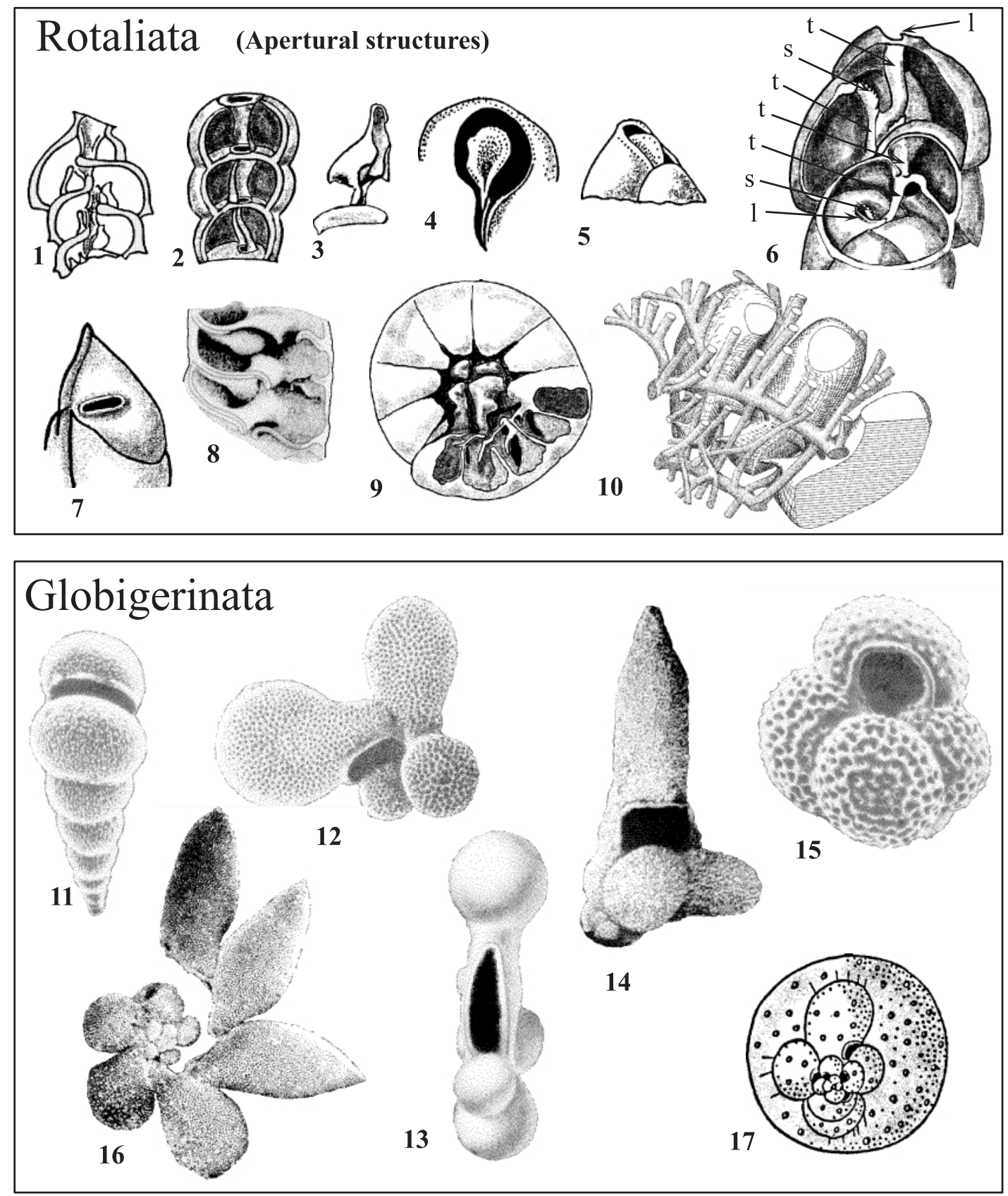

Explanation of Plate 5

Figs 1-10. Inner apertural structures of Rotaliata: 1, Uvigerina - inner apertural system of groove-plates (from Hofker, 1951); 2, Siphogenerinoides - inner apertural system of hemicylindrical groove-plates (from Montanaro Gallitelli, 1957); 3, Reussella - inner toothplate (from Loeblich \& Tappan, 1964); 4, Globobulimina - outer projecting fanlike part of the toothplate (inner parts forming inner apertural system) (from Höglund, 1947); 5, Bolivina - outer projecting broad short free part of the toothplate (inner parts forming inner apertural system); 6, Bulimina - complex inter-connected toothplates forming inner apertural system (l, apertural lip; s, free shank of the tooth plate; t, tooth plate (from Höglund, 1947)); 7, Osangularia - outer view of the last chamber with areal aperture; 8, Osangularia - inner part of the last chamber from the umbilical side showing bulging chamber ends, areal aperture, lip and indentation of apertural face runing to the apertural surface (from Reiss, 1960); 9, Ammonia - inner apertural valves forming inner apertural system (after Hottinger et al., 1993); 10, Rotalia - fragment of the canal system (from Hottinger, 1978). Figs 11-17. Aperture of Globigerinata: 11-15, high arched gaping aperture (11, Laterostomella; 12, Clavatorella; 13, Clavigerinella; 14, Beella; 15, Globoturborotalia); 16, Bolliella - uncoiling spire of the last whorl with inner open ends of the chambers; 17, Orbulina - multiple rounded apertures (larger than pores) on the surface of the last embracing chamber. 


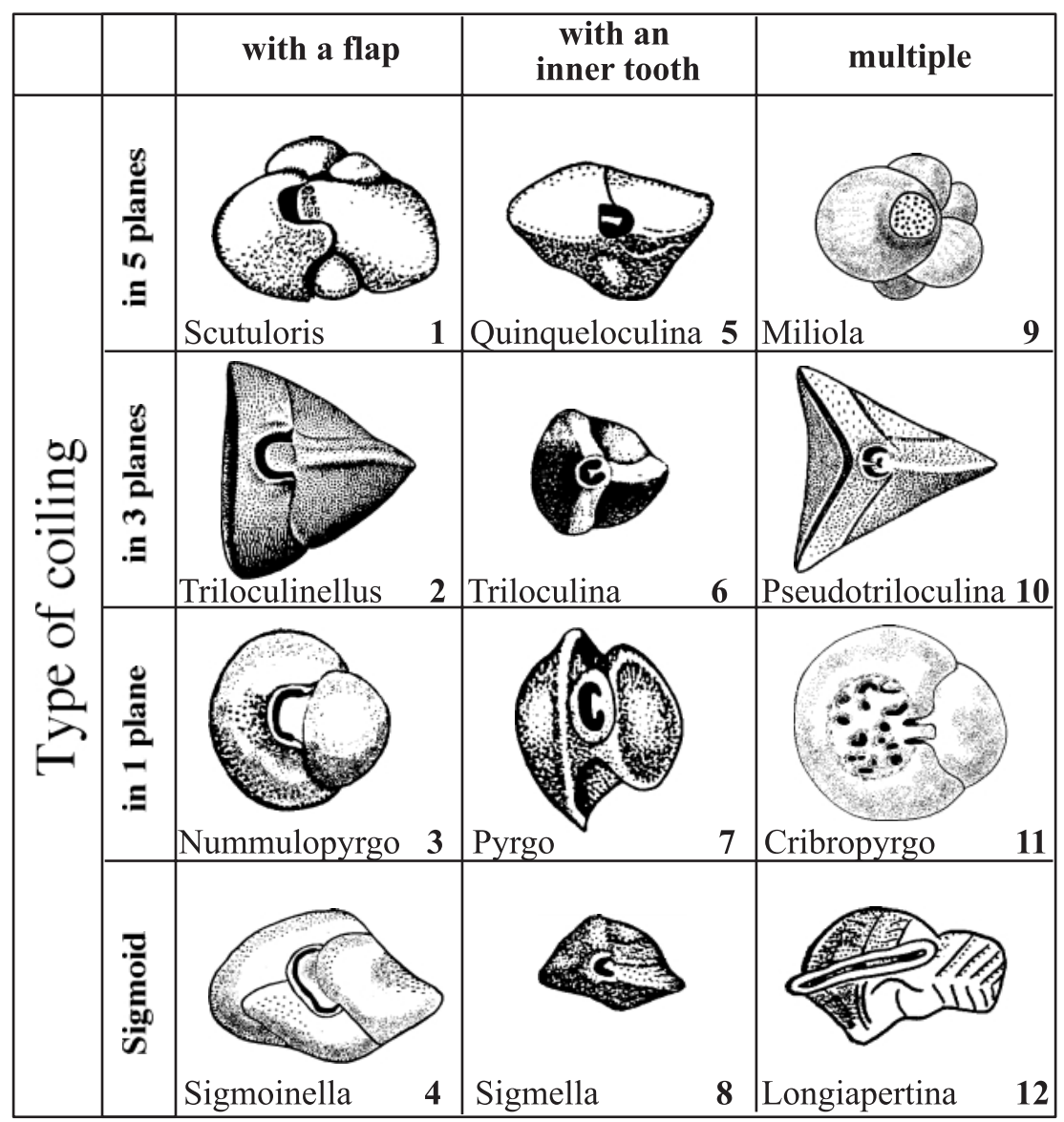

Explanation of Plate 6

Apertural structures in Miliolata with different miliolid chamber arrangements.

called a crista or comb (Pl. 5, fig. 6). The tooth-plates and the grooves of the successive chambers may be connected with each other forming a single system, linking all the chambers of the test together. This inner apertural apparatus plays an integrative role and is functionally similar to the canal system, differing from the latter in its structure and origin. It deserves a special name; the 'inner apertural system'. In the elongated forms of the agglutinated Textulariana, inner apertural complexities are more primitive than in the higher Rotaliana subclass: they may present a small inner protrusion, usually with thinner agglutinated material than the whole test wall, somewhat resembling the teeth of the agglutinated Schlumbergerinana but not analogous to them. However, rather complex inner tooth-plates, connected to each other in the successive chambers and forming a single system, were also described recently in Clavulina (Hottinger et al., 1993).

In the spirally coiled trochoid forms, inner apertural structures also exist, mostly in the umbilical area (Pl. 5, figs 7-9). For example, in the Discorbidae (Pl. 4, fig. 21), part of the chamber closest to the umbilical area, is separated from the main chamber by a non-perforate covering plate, which divides the aperture into two parts and partially covers it. This plate (=valve, foraminal plate) may be attached to the test wall or it may be not. The widened valve-like endings of the chambers in the umbilical area delimit funnel-shaped features connected with each other and with the umbilical area and forming a continuous structure in the test (Hansen \& Revets, 1992). The foraminal plates in Ammonia (Billman et al., 1980) and the inner apertural inflated chamber endings of Osangularia (Reiss, 1960) also form a single system (Pl. 5, figs 8, 9).

As can be seen from the foregoing discussion, the inner apertural structures of Rotaliata are well developed, achieving a high level of complexity. Unlike the Miliolata, they are not situated only in the apertural region, but sometimes occupy the major part of the chamber and may also extend through the whole chamber length. The system of stolons is also found in the multi-chambered tests of both subclasses.

\section{Canal system}

The higher degree of development of the apertural apparatus is the complex canal system that pierces all the tests between the chambers, in the spiral and radial septa, and is connected to additional openings in the sutures and in the umbilical area (Rotaliida, Nummulitida, Elphidiida) (Pl. 5, fig. 10). In foraminifera possessing a canal system, a higher degree of differentiation of the cytoplasm into endo and ectoplasm is achieved with the ectoplasm circulating in the canals (Hottinger, 1978; Billman et al., 1980). The canal system represents the 
unique integrative system at the organism level. Its presence diminishes the necessity of basic primary apertures which may disappear, being open only before the onset of the construction of a new chamber or in some other cases (e.g. Elphidium). The nature of this article does not allow us to discuss further the peculiarities of the canal system in the different groups of the Rotaliata.

\section{Additional apertures}

Additional apertures occur in various parts of the test. They may be connected with the canal system and may be formed in the places where the canal system opens: in the sutures, in the umbilical area or on the apertural face. However, they may also be found in many genera in which the canal system is absent, both in the agglutinated (Plotnikovina, Siphoniferoides) and in the calcareous forms (Helenina, Tremachora). To distinguish both types of additional apertures we hereafter name the former 'additional canal apertures' (or more simply 'canal apertures') to distinguish them from the usual additional (supplementary) apertures. This feature was traditionally used as a diagnostic character at the generic level. But the presence in higher taxa of a great number of genera with additional apertures could also serve as a diagnostic feature of the level of class in so far as the diversity in their structure and in the position of additional apertures is well developed. This is the case among the true multi-chambered tests only in the class Rotaliata (in both its subclasses) and in the class Globigerinata, derived from the latter. Additional apertures are practically absent from the other classes except in such a peculiar group as the Spirillinata.

\section{APERTURES IN GLOBIGERINATA (7)}

In the representatives of the young class Globigerinata (Jurassic-Recent), which we consider to have arisen from some earlier Rotaliata, the structure and the position of the main aperture is similar, in the main features, to that of the latter (P1. 5, figs 11-17), often being situated at the base of the apertural face of the last chamber. In the order Globorotaliida, the apertural features are similar to their rotaliid ancestors. As a result of the adaptation to a pelagic mode of life, a significant enlargement of the aperture in relation to the chamber surface took place in the orders Heterohelicida and Globigerinida: the arched aperture at the base of the apertural surface becomes high-arcuate (many of the species of Gumbelitria, Globigerina, Catapsydrax, Globigerinoides, Dentoglobigerina, Pulleniatina, Clavatorella, Clavihedbergella, Globanomalina and mainly Beella, Bolliella, and Hastigerinopsis) (P1. 5, figs 11-15). The aperture of Bolliella (Pl. 5, fig. 16) and Globigerinopsis enter so deeply into the spiral suture, that the test spire becomes nearly segmented, its coils being supported only by the cytoplasm. Like in representatives of the classes seen earlier, the Globigerinata aperture may also be multiple (Cribrohantkenina, Globigerinatella, Orbulina, Canorbulina) (P1. 5, fig. 17). In this case, the total surface of the aperture is increased on account of the multiplication of the openings. The additional apertures in the Globigerinata are even more developed than in the Rotaliata. In the last overlapping chamber of Orbulina, the multiple apertural openings are only little more in diameter than the pores and sometimes are wrongly confused with them.
Unlike the monoaxial elongated Rotaliata, the apertural neck is not developed in monoaxial Globigerinata (Heterohelicida). The inner apertural structures are also not developed in the Globigerinata except in some Chiloguembelinidae (Laterostomella).

\section{DISCUSSION}

This review of the development of the aperture in the different foraminiferal classes shows a significant number of examples of parallelism and convergence.

\section{Parallel evolutionary trends}

1. The development of the apertures from simple to complex ones with the formation of outer and/or inner additional structures occurs in parallel in most of the taxa (Pls 1-5; Fig. 1). Depending on the size of the inner apertural structures, their formation may be related to the compartmentalization and to the differentiation of the cytoplasm (Hottinger, 1982, 1986) either in the apertural area (Miliolata, Nodosariata, Rotaliata), in the whole chamber or even in the whole test (mostly in Rotaliata, but also in some Globigerinata (e.g. Laterostomella) and rarely in some Nodosariata (e.g. Ellipsopolymorphina, Ellipsoidina, Ellipsoidella).

2. The formation of an elongated apertural neck occurs in parallel in the monoaxial elongated forms of various taxa.

3. The multiplication of the number of apertural openings (from single to secondary multiple and cribrate), considered as a polymerization process, is a parallel evolutionary trend in all classes with multi-chambered tests (Pls 2-6; Fig. 1). In the most primitive unilocular forms, the process of oligomerization from the primary multiple aperture to a single one, preceding the secondary polymerization, also occurs in parallel.

4. The additional apertures arise in parallel in higher Spirillinata and in Rotaliata.

5. The displacement of the aperture from the periphery to the umbilical side and even to an umbilical position is a parallel evolutionary trend in the trochoid forms.

6. Stolons are formed in parallel in the multi-chambered tests of Miliolata and Rotaliata.

7. Canal systems are formed in parallel in higher Spirillinata and in Rotaliata.

Parallel evolutionary trends, including minute changes in the apertural structure, occur more often in the closely related groups belonging to the same class. In the subclass Textulariana, for example, it is possible to distinguish parallel lineages of forms possessing multiple apertures in almost all the families of the orders Lituolida, Textulariida, Trochamminida, and Ataxophragmiida. In the same way, it is possible to outline the parallel development of the inner apertural structures from small teeth and small plates up to complex grooves, plates, hemicylindrical siphons and, finally, to tubes in the different orders and families of the superorder Buliminoida.

\section{Convergent evolutionary trends}

1. The inner apertural structures in the Miliolata, Nodosariata and Rotaliata could be regarded as convergent features 


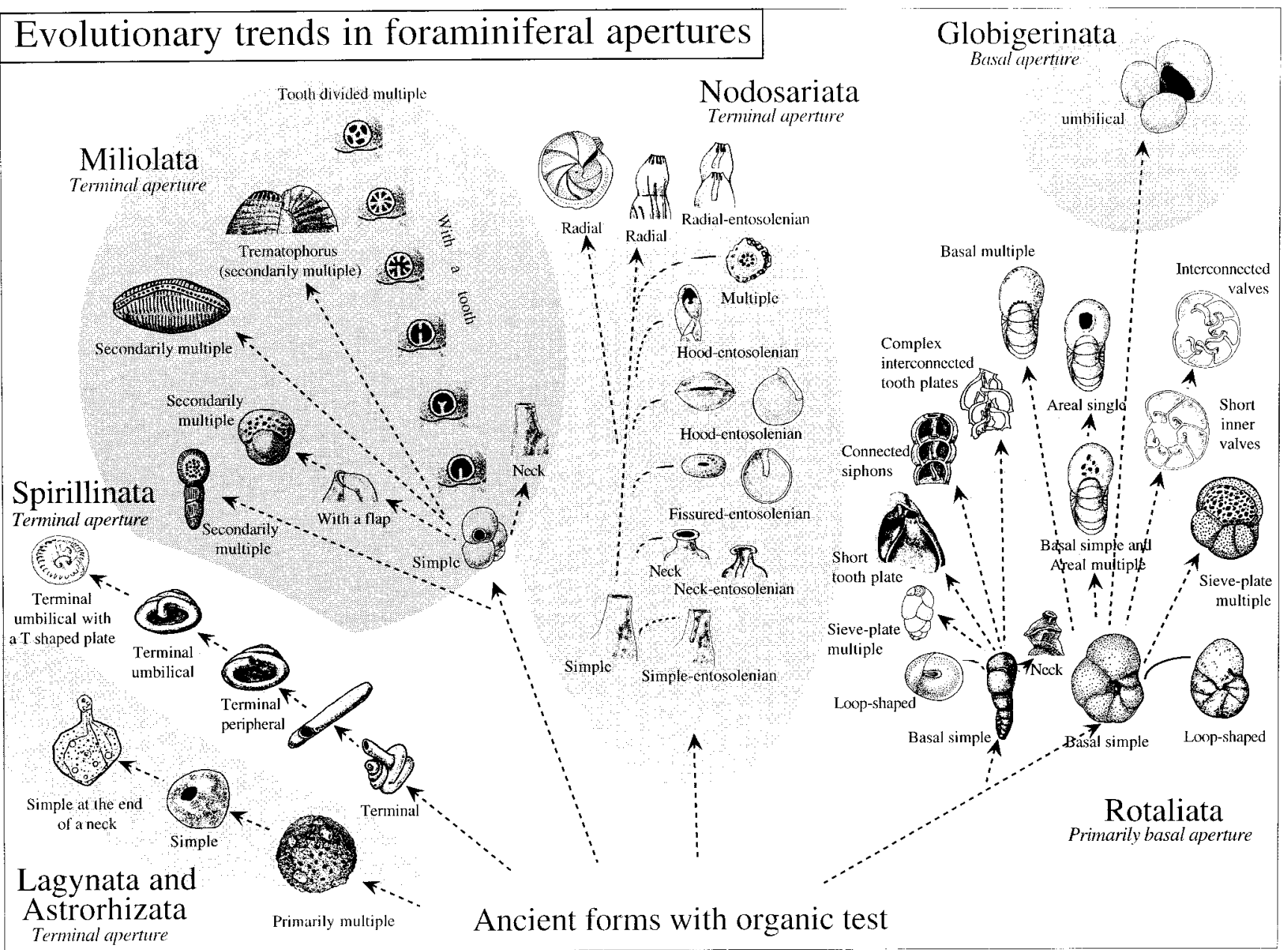

Fig. 1. The scheme of evolutionary trends in the foraminiferal aperture.

as they have different morphological origin, but have the same functional significance. The entosolenian tubes in Nodosariata tests (Pl. 3) and the siphons in the aperture of the Rotaliata, as well as the inner apertural systems that may be associated with them (Pl. 5) are examples of this convergence. The radiate terminal apertural structures are also sometimes formed in some miliolids, convergently with the Nodosariata radial aperture, but on another morphological basis.

2. Multiple apertures may also be considered as convergently formed structures as they result from various origin and formation processes:

- simple additional openings on the test surface of the last chamber - 'simple (areal) multiple aperture' (Pl. 2; fig. 26; Pl.3, figs 26, 27; Pl. 4, figs 23, 28, 29, 33, 36; Pl. 6, fig. 11);

- multiple openings in a special plate, covering the aperture - 'sieve-plate multiple aperture' (P1. 4, figs 34, 35, 37, 38);

- transformation of the tooth apparatus in Miliolata 'tooth divided multiple aperture' (Pl. 2, figs 15, 16, 18-20; Pl. 6, fig. 10);
- evolution of the radial aperture in Nodosariata - 'radial multiple aperture' (Pl. 3, figs 23-25).

Convergent modes of formation of the multiple aperture may occur even within the limits of one class as it does clearly appear in Miliolata, for example.

\section{General considerations}

The great variability of test morphology associated with the high diversity of habitats of fossil and Recent forms suggests that the foraminifera used nearly all the possible combinations of adaptative features which comprise the universal space of possibilities. The frequent parallel evolution in forms belonging to close phylogenetic branches may be explained by the fact that closely related organisms derived from close forms have the same adaptative possibilities. As a result, it is possible to predict the apertural structure of definite forms on the basis of the possible combinations of known apertural features. For example, the different types of miliolid aperture (flap, simple tooth, multiple aperture) may be combined with the different modes of chamber arrangement (quinqueloculine, triloculine, 
biloculine, sigmoidal, spiroloculine) (Pl. 6). Some of the genera of the Miliolata were separated recently. For example, Sigmoinella (Saidova, 1975), Sigmella (Azbel \& Mikhalevich, 1983, in Mikhalevich, 1983) and Longiapertina (Seiglie \& Bermudez, 1966), illustrated on Plate 6. The last named was described as having one or two rows of openings in adult forms. However, Loeblich \& Tappan (1988) consider it as having a simple elongate aperture. If this is the case, then forms with a sigmoidal test structure and a multiple aperture may still be discovered in the future. These examples show the prognostic value of a system based on morphological structures, even if many unresolved questions still remain.

In all types of foraminifera, the first stages of complexity in the apertural structure appear in a great number of parallel evolutionary trends: the formation of a neck, a border, a collar, a lip, or of multiple openings. These evolutionary trends continue until all the possibilities of the former structures have been exhausted. Then, new structures sometimes affecting the whole cell organization arise, and the possibilities of morphological change become more abundant, leading to evolutionary divergence.

The phylogenetic development of the various lineages achieved different levels of organization and each class possesses its own peculiar features (P1. 1-6; Fig. 1). The simplest and least diverse apertural types are found in the most ancient unilocular or pseudo-chambered representatives of the classes Lagynata and Astrorhizata. In these classes, the primary multiple aperture is often present in the less advanced forms, but in the more advanced forms almost exclusively outer apertural structures are developed. In the pseudo-bilocular representatives of the class Spirillinata, as ancient as the previous two classes, the apertures are also very primitive: the terminal opening at the end of the tubular pseudo-chamber is simple, generally without any outer structure, even the simplest ones (neck, border). Only the rare higher representatives may possess a peculiar curved external apertural plate. Despite these very primitive apertural features, some very progressive characteristics can be observed in some higher representatives such as the presence of additional apertures and of a primitive canal system or the tendency of the displacement of the aperture from the periphery to the umbilical side in the trochospiral calcareous forms (Conicospirillina, Mychostomina).

The simplest outer apertural formations observed in Lagynata and Astrorhizata (neck, border, lip) also occur in the primitive representatives, mostly elongated monoaxial in morphology, of the Miliolata, Nodosariata and even Rotaliata (Pls 2, 3, 4; Fig. 1). However, these classes, as well as the class Globigerinata, also develop inner apertural structures and even integrative apertural systems (stolons, inner apertural systems, canal systems) in their multi-chambered tests. The inner structures differ in each class, as well as the integrative systems. The Miliolata have only stolons; the Nodosariata and Globigerinata only rarely have inner apertural systems; The Spirillinata only seldom have a simple canal system. Only the Rotaliata have the three integrative apertural systems well developed, reaching the highest degree of complexity, mainly in the canal system (if present). This class, and the related Globigerinata, also have the most developed and diversified additional apertures.
In the classificatory system proposed earlier by Mikhalevich (1980-98), on the basis of the evolution of the test, of the test wall texture and of some of the cytoplasmic structures, the different representatives of the former heterogeneous Textulariina (Loeblich \& Tappan, 1988 [=Textulariacea in Loeblich \& Tappan, 1964]) are placed into the lower subclasses of the Spirillinata, Miliolata and Nodosariata, and into the separate class Astrorhizata according to their test and apertural morphology. The result is that the classes Spirillinata, Miliolata, Nodosariata and Rotaliata of this system are composed of both lower agglutinated groups and higher calcareous ones. In both lower and higher groups of the same class, the evolutionary trends of the position and of the structure of the apertures are similar, even if those of the lower groups are always structurally more simple and less diversified. These similarities clearly show the close relationship between these groups and confirm that the classes proposed by Mikhalevich correspond to separate and specific phylogenetic lineages.

\section{ACKNOWLEDGEMENTS}

The work is supported by RFFI, project 97-04-48 359. The authors are thankful to Professor Ja. I. Starobogatov of the Zoological Institute, Russian Academy of Sciences for his consultation on the evolutionary regularities in different groups of the Animal and Plant Kingdoms. The authors are very grateful to J. Whittaker and the anonymous referee for their very constructive and thorough review that contribute to improve considerably the manuscript.

\section{Manuscript received 12 July 1999 \\ Manuscript accepted 10 March 2001}

\section{REFERENCES}

Banner, F. T. 1988. Review: Foraminiferal genera and their classification by Alfred R. Loeblich and Helen Tappan. British Micropaleontological Society Newsletter, 36: 13-15.

Billman, H., Hottinger, L. \& Oesterle, H. 1980. Neogene to Recent rotaliid foraminifera from the Indopacific Ocean; their canal system, their classification and their stratigraphic use. Schweizerische Paläontologische Abhandlungen, 101: 71-113.

Cushman, J. A. 1928. Foraminifera their classification and economic use. Cushman Laboratory for Foraminiferal Research Special Publication, 1: 1-401, pl. 1-59.

Debenay, J-P., Pawlowski, J. \& Decrouez, D. 1996. Les foraminifères actuels. Editions Masson, Paris, 329pp.

Decrouez, D. 1989. Generic ranges of Foraminiferida. Revue de Paléobiologie, Genève, 8: 263-321.

Didkov'skij, V. Ja. 1957. (O novom predstavitele semeystva Miliolidae Tortonella bondartschuki gen. et sp. nov. Iz Tortonskikh otlozheniy USSR. Doklady Akademii Nauk SSSR, 113. P. 1137-1139). On a new representative of the family Miliolidae, Tortonella bondartschuki gen. et sp. nov. from Tortonian strata of the USSR. Reports of the Zoological Institute of USSR Academy of Sciences, 113: 1137-1139.

Haman, D. 1988. Review: Foraminiferal genera and their classification by Alfred R. Loeblich and Helen Tappan. Journal of Foraminiferal Research, 18: 271-274.

Hansen, H. J. \& Revets, S. A. 1992. A critical revision and reclassification of the Discorbidae, Rosalinidae and Rotaliidae. Journal of Foraminiferal Research, 22: 166-180.

Hart, M. B. \& Williams, C. L. 1993. Protozoa. In Benton, M. J. (Ed.), The Fossil Record 2, 43-70. Chapman \& Hall, London.

Haynes, J. R. 1990. The classification of the foraminifera - a review of historical and philosophical perspectives. Palaeontology, 33: 503-528. 
Hofker, J. 1951. The foraminifera of the Siboga expedition. Part 3 Siboga Expeditie. Monographie IVa. E. J. Brill, Leiden, 1-513.

Hofker, J. 1956. Foraminifera Dentata. Foraminifera of Santa Cruz and Thatch-Island Virginia Archipelago, West Indies. Spolia Zoologica Musei Hauniensis, 15: 1-237.

Hofker, J. 1969. Recent foraminifera from Barbados. Studies of the Fauna of Curaçao and other Caribbean Islands, The Hague, 31/115: $1-158$.

Hofker, J. 1970. Studies of foraminifera. Pt II, Systematic problems. Publicaties van het Natuurhistorisch Genoostschap Limburg, 20: 1-98.

Höglund, H. 1947. Foraminifera in the Gullmar Fjord and the Skagerrak. Zoologiska Bidrag fran Uppsala, 26: 1-328.

Hottinger, L. 1978. Comparative anatomy of elementary shell structures in selected larger foraminifera. In Hedley, R. H. \& Adams, C. G. (Eds), Foraminifera 3, 203-266. Academic Press, London.

Hottinger, L. 1982. Larger foraminifera, giant cells with a historical background. Naturwissenschaften, 69: 361-371.

Hottinger, L. 1986. Construction, structure, and function of foraminiferal shells. In Leadbeater, B. S. C. \& Riding, R. (Eds), Biomineralization in Lower Plants and Animals, 219-235. Special publication of the Systematics Association, 30.

Hottinger, L., Halicz, E. \& Reiss, Z. 1993. Recent Foraminiferida from the Gulf of Aqaba, Red Sea. Dela SAZU, Ljubljana, 33, VI+179 pp.

Kohl, B. 1985. Early Pliocene foraminifers from the Salina Basin, Southeastern Mexico. Bulletins of American Paleontology, 88: 1-173.

Le Calvez, J. 1947. Entosolenia marginata, foraminifère apogamique ectoparasite d'un autre foraminifère Discorbis vilardeboanus. Compte Rendus de l'Académie des Sciences, 224: 1448-1450.

Lee, J. J. 1990. Phylum Granuloreticulosa (Foraminifera). In Corliss, J. O. (Ed.), Handbook of Protoctista. Boston, 914pp.

Levy, A., Mathieu, R., Poignant, A. \& Rosset-Moulinier, M. 1991. Morphologie et morphométrie de foraminifères benthiques (Miliolacea) du Cénozoïque à l'actuel. Géobios, 13: 97-104.

Loeblich, A. R. \& Tappan, H. 1964. Sarcodina, chiefly 'Thecamoebians' and Foraminiferida. In Moore, R. C. (Ed.), Treatise on Invertebrate Paleontology. Geological Society of America/University of Kansas Press, New York, 1, 1-510; 2, 511-900.

Loeblich, A. R. \& Tappan, H. 1988. Foraminiferal Genera and their Classification. Van Nostrand Reinhold Company, New York, 1, 970pp; 2, 847 pl.

Loeblich, A. R. \& Tappan, H. 1992. Present Status of Foraminiferal Classification. Studies in Benthic Foraminifera BENTHOS '90, Sendai, 1990. Tokai University Press, 93-102.

Luczkowska, E. 1972. Miliolidae (Foraminiferida) from Miocene of Poland. Part 1: Revision of the classification. Acta Palaeontologica Polonica, 17: 341-377.

Margulis, L. \& Schwartz, K. V. 1988. Five Kingdoms, [second edition]. W.H. Freeman and Company, New York.

Margulis, L. 1974. Five kingdom classification and the origin and evolution of cells. In Dobzhansky, T., Hecht, M. K. \& Steer, W. C. (Eds), Evolutionary Biology, 45-78. Plenum press, New York.

Mikhalevich, V. I. 1980. (Sistematika i yevolyuciya foraminifer v svete novyikh dannyikh po ikh citologii i ul'trastrukture. V kn.: Principy postroeniya makrosistemy odnokletochnyikh zhivotnyikh. $\mathrm{Tr}$. Zool.in-ta AN SSSR. L. T. 94. S. 42-61.). Taxonomy and evolution of the foraminifera in the light of the new data on their cytology and ultrastructure. In : The principles of the formation of the macrosystem of the unicellular animals. Proceedings of the Zoological Institute of USSR Academy of Sciences, 94: 42-61.

Mikhalevich, V. I. 1983. (Donnyie Foraminiferyi shel'fov tropicheskoj Atlantiki. Zool. Inst AN SSSR. L. 247 S. 26 tabl.). The bottom foraminifera of the shelves of the Tropical Atlantic. Proceedings of the Zoological Institute of USSR Academy of Sciences, 247, 26 pls.

Mikhalevich, V. I. 1988. (Sistema podklassa Miliolata (Foraminifera). V kn.: Sistematika, yekologiya i stratigrafiya miliolyat (Foraminifery). Pod red. V.I. Mikhalevich. L. Tr. Zool. in-ta AN SSSR. T. 184. S.
77-110. 8 tabl. s ris.). The systematics of the subclass Miliolata (Foraminifera). In Mikhalevich, Q. I. (Ed.), Taxonomy, ecology and stratigraphy of Miliolata (Foraminifera), Proceedings of the Zoological Institute of USSR Academy of Sciences 184, 77-110, 8 pls.

Mikhalevich, V. I. 1992. (Makrosistema foraminifer. Avtoref. dokt. diss. $S-P b$. Zool. in- $t$ RAN. $43 \mathrm{~S}$.) The macrosystem of the Foraminifera. $\mathrm{PhD}$ thesis. S.-Pb. Zool. Inst. Russian Akad. Sci., 43pp.

Mikhalevich, V. I. 1993. New higher taxa of the subclass Nodosariata (Foraminifera). Zoosystematica Rossica, 2: 5-8.

Mikhalevich, V. I. 1995. A new classification of the class Astrorhizata (Foraminifera). Zoosystematica Rossica, 3: 161-174.

Mikhalevich, V. I. 1997a. The new conception of the foraminiferal macrosystem The first international conference 'Application of Micropaleontology in Environmental Sciences', Tel-Aviv, 15-20 June 1997. Abstract, 88-89.

Mikhalevich, V. I. 1997b. Main directions of the foraminiferal evolution Evolution of Life on the Earth. Omsk, 44-45.

Mikhalevich, V. I. 1998. (Makrosistema foraminifer. Izv. RAN. N 2. Ser. biol. V pech.) The Macrosystem of the Foraminifera. Izvestija of the Russian Academy of Sciences, Ser. Biol, 2: 266-271.

Mikhalevich, V. I. 1999. (Sistematika i philogenia Foraminifer) The Foraminiferal System and Phylogeny, 176pp.

Montanaro Gallitelli, E. 1957. A revision of the foraminiferal family Heterohelicidae. Bulletin of the United States National Museum, 215: $133-154$

Müller-Merz, E. 1980. Structural analysis of selected rotaliid foraminifera. In Hottinger, L. (Ed.), Rotaliid foraminifera. Schweizerische Paläontolische Abhandlungen, 101, 5-70.

Munier-Chalmas, E. \& Schlumberger, C. 1885. Note sur les miliolidées trématoforées. Bulletin de la Société Géologique de France ser.3, 13: 273-323.

Patterson, R. T. \& Pettis, R. H. 1986. Galwayella, a new foraminiferal genus an newnames for three foraminiferal homonyms. Journal of Foraminiferal Research, 16: 74-75.

Patterson, R. T. \& Richardson, R. H. 1987. A taxonomic revision of the unilocular foraminifera. Journal of Foraminiferal Research, 17: 212-226.

Pawlowski, J., Bolivar, I., Farhni, J., Vargas, C. de \& Bowser, S. S. 1999. Naked foraminiferans revealed. Nature, 399: 27.

Plotnikova, L. F. 1991. Vendskie foraminifery Podolii (The foraminifera of the Vend in Podiola). Geological journal, Kiev, 3: 25-42.

Ponder, R. W. 1972. Pseudohauerina, a new genus of the Miliolidae and notes on three of its species. Journal of Foraminiferal Research, 2 $145-156$.

Poore, R. Z. \& Gosnell, L. B. 1985. Apertural features and surface texture of upper Paleogene biserial planktonic foraminifers links between Chiloguembelina and Streptochilus. Journal of Foraminiferal Research, 15: 1-5.

Reiss, Z. 1960. Structure of so-called Eponides and some other rotaliform foraminifera. Bulletin of the Geological Survey of Israel, 29: $1-28$.

Revets, S. A. 1996. The generic revision of five families of rotaliine foraminifera. Cushman Foundation for Foraminiferal Research. Special Publication, 34, 113pp.

Saidova, Kh. M. 1975. (Bentosnye Foraminifery Tikhogo Okeana) Benthonic foraminifera of the Pacific Ocean. Inst. Okeanologii P.P. shirshova, Akademiya Nauk SSSR, Moscow, 3 vol.

Seiglie, G. A. \& Bermudez, P. J. 1966. Tres generos nuevos y una especie nueva de foraminieros de terciario de las Antillas. Eclogae Geologicae Helvetiae, 59: 431-435.

Silvestri, A. 1904. Forme nuove o poco conosciute di Protozoi Miocenici piemontesi. Atti dell' Accademia della Scienze di Torino, 39: 4-15.

Taylor, S. H., Patterson, R. T. \& Choi, H. W. 1985. Occurrence and reliability of internal morphologic features in some Glandulinidae (Foraminiferida). Journal of Foraminiferal Research, 15: 18-23. 